\title{
PERSONNEL CERTIFICATION AS A NECESSARY CONDITION FOR ENTERPRISE' STAFF DEVELOPMENT
}

\author{
Sviatoslav KIS, Larysa MOSORA, Yurii MOSORA, Oleh YATSIUK, Galyna MALYNOVSKA, Serhii POBIHUN \\ Ivano-Frankivsk National Technical University of Oil and Gas
}

\begin{abstract}
:
The theoretical research and substantiation of specialists compliance estimation with corporate requirements on the basis of international certification and determination of its role in the system of enterprise' staff management are carried out in the article. The algorithm of the enterprise' effect achievement of the preliminary international certification of the personnel involved in oil and gas wells drilling is offered. The relationship between the number of persons trained and certified by International Well Control Forum in Drilling Simulation Center of the Ivano-Frankivsk National Technical University of Oil and Gas and the volume of drilling of oil and gas wells in Ukraine is analyzed. The task was accomplished by means of correlation and regression analysis. The results of the calculations allow us to make sufficiently plausible assumptions about the impact of training and certification on drilling volumes. It is established that the increase in the number of persons certified according to International Well Control Forum for one person will allow to expect the volume of drilling of oil and gas wells by 0.734 thousand metres per year.
\end{abstract}

Key words: personnel certification, enterprises' technical staff, correlation and regression analysis, well drilling

\section{INTRODUCTION}

Personnel certification procedures are gaining increasing popularity in developed countries. This is due to the real needs of organizations in highly qualified personnel, whose competence can be confirmed not only by a diploma of education obtained in an educational institution, but also a certificate, which will certify the passing of a person of additional professional training, the presence of her unique and relevant knowledge and skills. In the modern world, the problem of forming a system of personnel certification is extremely urgent, since the achievement of economic and social goals of the state (improving the competitiveness of the domestic economy, labor resources, educational services, etc.) is impossible without the provision of high quality and continuous improvement of labor resources [1, 7, 8, 12].

Substantiating the new approaches to enhancing the domestic enterprises competitiveness, the crucial role is to strengthen the direct interdependence between the potential of staff, the development of their competencies and the increase of productivity, quality of work and efficiency of production sphere functioning. Requirements for the availability of competent personnel at enterprises are set by international quality standards.

In modern conditions one of the effective means of ensuring the proper level of employees competence, as evidenced by practical experience and scientific research $[2,4,13,20,21]$, is the personnel certification for compliance with workplaces corporate requirements. To achieve this goal, it is necessary to provide the latest theoretical substantiation of requirements for the employees competencies, to conduct an assessment based on certification of the most important professions and positions as one of the main areas of enterprises strategic personnel management.

\section{LITERATURE REVIEW}

Theoretical and practical bases of assessment of competencies of the personnel of firms and organizations and some issues of its certification were considered in their works by foreign scholars and practitioners: $H$. Aguinis $[1,2], M$. L. Lengnick-Hall [11], S. W. Lester [12, 13], J. McKillip [15], D. M. Rousseau [18], D. J. Cohen [4], A. S. DeNisi [5], G. P. Latham [10], A. S. Garza [6], E. A. Locke [14], W. F. Cascio [3], R. A. Paxton [17] and others.

The works of Ukrainian scientists S. Kis [7, 8], Ya. L. Zakharchenko [21], N. Volkova [19], V. S. Zaitsev [20], V. I. Kolisnyk [9] and others are devoted to studies on assessing the competencies of enterprise staff based on the application of certification. They considered the specialists certification as a factor in improving products quality, the goals and objectives of personnel certification, its importance and benefits for businesses and employees, methods of staff evaluation. At the same time it should be noted that in the conditions of technic and technology constant complication the personnel certification value is constantly increasing, so this method requires further scientific and applied development and adaptation to modern business conditions. 
Briefly summarizing the review of literature $[1,2,3,4,5,6$, $7,8,9,10,11,12,13,14,15,17,18,19,20,21]$, it should be noted that today the knowledge gained in educational institutions is becoming rather obsolete due to the emergence of new scientific advances and the development of technologies. In this regard, the specialist must constantly pass retraining in order to maintain their knowledge and skills at the required level. Otherwise, it risks being unnecessary in the labor market.

The narrow specialization and unique knowledge and skills required for a particular organization or for a particular project cannot be obtained in mainstream educational institutions, where specialists are graduated en masse without taking into full account the specific requirements of organizations and the economic environment. This deficiency can be eliminated by organizing additional training of employees $[1,2,5,6,11,13,14,15]$. It should also be noted that in an unstable economic environment, professionals often change jobs. In this case, a specialist must confirm (usually documented) his competence at a new place, in particular, undergoing additional training [12, 20, 21]. All these facts substantially enhance the relevance of our research.

The need for international certification of specialists on oil and gas wells drilling who directly carry out drilling operations and are responsible for their carrying out, in the direction of "Drilling Well Control Surface" is due to features that occur during drilling and are the cause of fluid manifestations. Without denying the need to use technical and technological innovations to minimize the accident during drilling operations, it is necessary to agree with the authors of the research $[7,9,16]$, that the main reason for the occurrence and negative consequences of freelance situations is the lack of performers qualification and their failure to perform priority actions.

\section{RESEARCH METHODOLOGY}

For the drilling company, two options for the development of the production process can be predicted if the well is operated by certified and non-certified personnel. The algorithm of enterprise effect achievement from the previous international certification of the personnel involved in the drilling of oil and gas wells is presented in Fig. 1.

Based on the block diagram proposed in Fig. 1, it can be assumed that the achievement of negative (positive) social, ecological and economic consequences when drilling wells occurs in three stages, each of which is characterized by staff participation.

In Phase I, the management personnel of the drilling company, in accordance with the authority provided by the job responsibilities, determine the range of tasks that production personnel need to undertake to ensure the drilling process.

In Phase II, responsible persons identify and evaluate the need to use technical and technological solutions to avoid dangerous emergencies when drilling wells. It should be noted that some of the tasks provided by the drilling process are traditionally standardized and do not involve any changes to regulations, technologies, tools, and others require non-standard decisions.

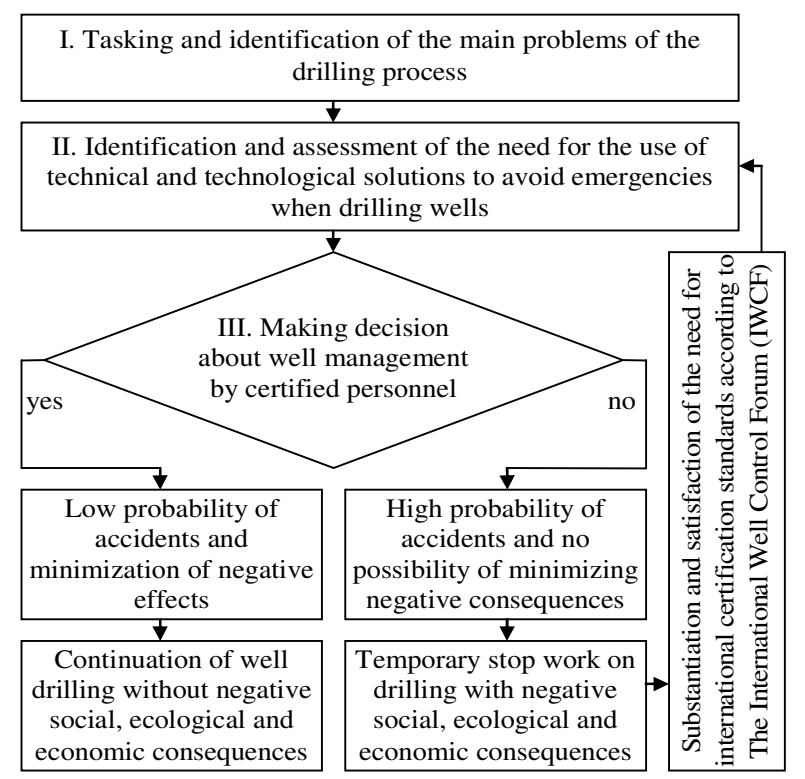

Fig. 1 Block diagram of the achievement of negative (positive) social, ecological and economic consequences during well drilling

In Phase III, the completion of the tasks and the solution of the main problems that occur when drilling is ongoing. However there are two scenarios:

1) decision-making on the task solution, economic, social, environmental and other consequences of the impact on the enterprise activity results are foreseen and substantiated by certified personnel, on the basis of specific knowledge, skills, experience acquired in the certification process;

2) making decisions that substantiate the impact on the enterprise performance is limited by the capabilities of personnel who do not have the skills to work in nonstandard drilling situations.

By our assumption, in the first case the drilling company operates in a regular mode, there is no additional financial costs, as well as social and environmental commitments. In the second, the enterprise is characterized by a temporary suspension of well drilling, with unpredicted economic, social and environmental losses. Under these conditions, to restore drilling operations, it is necessary, first of all, to eliminate the negative consequences of the emergency, and then to return to the second stage (Fig. 1), having previously undertaken personnel training and certification. The results of the certification of the drilling personnel responsible directly for oil and gas wells drilling operations can be assessed by analyzing the relationship between the number of people trained and certified by International Well Control Forum (IWCF) in the Drilling Simulation Center (the only simulation center in Ukraine that certifies IWCF technical drilling personnel) of Ivano-Frankivsk National Technical University of Oil and Gas (IFNTUOG) and volumes of oil and gas wells drilling in Ukraine.

It is proposed to accomplish this task by means of correlation and regression analysis. The close relationship between these indicators will indicate: 
1) making decision by management of drilling companies on rational operation of oil ang gas well drilling by certified technical personnel;

2) the need for certification of technical personnel by drilling companies in order to avoid accidents when drilling oil ang gas wells and, accordingly, to ensure positive dynamics of drilling volumes.

\section{RESEARCH RESULTS}

Successful development of Ukrainian oil and gas industry on the basis of modern energy-saving technologies is largely determined by the state of employees professional training of all levels, and above all those whose activities are closely related to production and technological processes. A full-fledged provision of oil and gas companies with qualified personnel enables to attract competitive specialists to work both in the domestic market and in international projects. The integration of the Ukrainian economy into the world community requires companies to make significantly new demands, both on the educational and cultural level of employees and on the level of professional skill of employees, as the most important factor of professional competence.

To confirm the professional competence of oil and gas personnel in economically developed countries of the world, a certification system is functioning, according to which the qualification of an employee is confirmed by a certificate of conformity recognized in international labor markets. It is important to note that in these countries, the certification of staff is mandatory, as a diploma of education obtained at an educational institution certifies only the educational level of the specialist. At the same time, the real staffing needs of the world's leading oil and gas companies are met by certified specialists who receive their certification at relevant institutions with international accreditation. Having an international certificate a specialist certifies his/her additional professional training, profound assessment of his/her knowledge and practical and professional competences.

As the specifics of oil and gas wells drilling operations require the specialists with creative approach, making in extreme situations correct and sometimes extraordinary decisions, the international certification for specialists of Ukrainian drilling enterprises is a requirement of a modern approach to the process of drilling in various geological and technical conditions. Having international accreditation and the right to certificate the drill specialists in the field of "Drilling Well Control Surface" according to the requirements of the most reputable IWCF profile, IFNTUOG has been providing internationally certified certification services for over fifteen years.

The need for international certification for professionals who are directly engaged in oil and gas wells drilling and responsible for their drilling, is explained by a number of strong arguments. Drilling wells on land and at sea always leads to a violation of the natural equilibrium in the earth's interior. And as the conditions of prospecting and operational drilling for oil and gas deposits are constantly complicated, the disclosure of unknown horizons at different depths increases the probability of hydrostatic equilibrium loss in the "well-reservoir" system, which is the root cause of the fluids occurrence. In such situation, the lack of qualification of the main performers and their failure to perform priority actions, and often panic, can lead to an open oil and gas fountain. If human casualties are avoided, environmental degradation in the surrounding area and significant material costs are inevitable [16, p. 68].

The presence in IFNTUOG of modern facilities and qualified personnel who have confirmed their professional and teaching level in foreign certification centers, as well as the installation and commissioning of the simulator-drilling rig DRILLSIM 5000 have become the main factors, the implementation of which creates the conditions for the fairs Ukraine's oil and gas sector in international scientific and technical cooperation and is an important stage of fruitful cooperation between IFNTUOG and leading oil and gas companies in Ukraine [9].

Oil and gas companies that have internationally certified stuff, have the opportunity to enjoy the following priorities:

1) to position itself as a company that meets the requirements of international labor markets to provide services with its personnel for wells construction;

2) ensure the requirements of the contracting authority in the technological disciplines of the well construction process and guarantee the safety of the environment, health and property due to the competence of the certified personnel;

3) to gain advantage in investing and lending to the enterprise;

4) provide one of the mandatory conditions (availability of certified personnel) for participation in international tenders and projects;

5) confirmation of the enterprise image and possibility of services rendering realization for wells construction at reasonable prices;

6) the fact of proof to the customers and partners in the oil and gas business of their competitiveness;

7) the opportunity to obtain an actual assessment of the professional competence and professional suitability of the staff.

The course involves the study of the following issues: the main parameters of hydrocarbon reservoirs, reservoir pressure and the identification of an increase in reservoir pressure, well pressure, methods of blockage of the wells, equipment for well monitoring, as well as the basic mathematics required to calculate the volume of the wellbore. The course is held in the form of lectures with video presentations, practical exercises, homework, practical work on a drilling simulator, and upon completion of training, candidates pass 2 written exams under the supervision of an independent IWCF examiner and a practical exam on a drilling simulator.

Passing the training course and passing the written and drilling simulator exam with an IWCF Certificate provides certification for oil and gas wells drilling with the use of ground or underwater bumper equipment. The IWCF certificate confirms well control competence and is valid for two years. The number of people who have received training and certification in the Drilling Simulation Center (DSC) 
of IFNTUOG is shown in Table 1, and their dynamics is shown in Fig. 2.

Table 1

Number of persons certified under IWCF and amount of oil and gas well drilling in Ukraine in 2005-2019

\begin{tabular}{ccc}
\hline Years & $\begin{array}{c}\text { Number of persons who have } \\
\text { received training and } \\
\text { certification at DSC of IFNTUNG, } \\
\text { persons }\end{array}$ & $\begin{array}{c}\text { Amount of oil and } \\
\text { gas well drilling in } \\
\text { Ukraine, thousand m }\end{array}$ \\
\hline 2005 & 56 & 280 \\
2006 & 65 & 280 \\
2007 & 85 & 275 \\
2008 & 76 & 275 \\
2009 & 65 & 275 \\
2010 & 75 & 250 \\
2011 & 66 & 270 \\
2012 & 62 & 270 \\
2013 & 66 & 210 \\
2014 & 48 & 190 \\
2015 & 15 & 195 \\
2016 & 5 & 210 \\
2017 & 5 & 250 \\
2018 & 23 & 290 \\
2019 & 193 & 370 \\
\hline
\end{tabular}

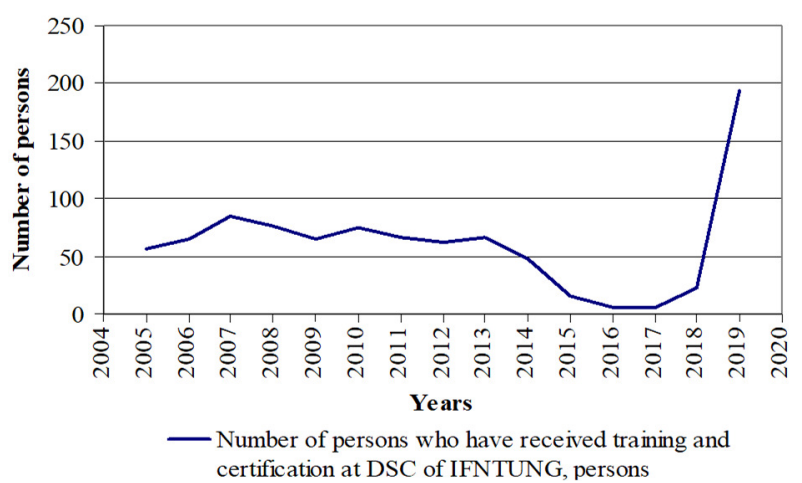

Fig. 2 Dynamics of number of persons who have received training and certification at DSC of IFNTUNG in 2005-2019

To evaluate the performance of the certification of drilling plant technical personnel, we will conduct a study of the relationship between the number of certified persons and the volume of drilling of oil and gas wells in Ukraine using correlation and regression analysis tools. The volumes of drilling of oil and gas wells in Ukraine are shown in Table 1, and their dynamics is shown in Fig. 3.

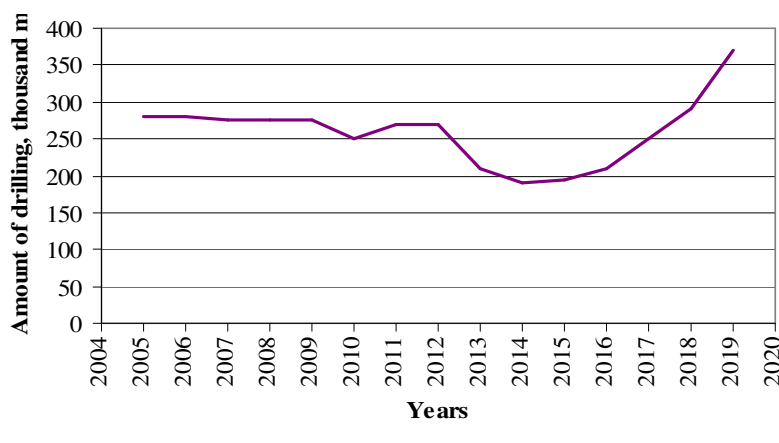

Fig. 3 Dynamics of amount of oil and gas well drilling in Ukraine in 2005-2019

A visual analysis of the dynamics of indicators of the number of persons who have been trained and certified (Fig. 2) and the volume of drilling (Fig. 3 ) suggests that there is a certain econometric relationship between the studied indicators. Based on the presented data, we construct a scatterplot (Fig. 4).

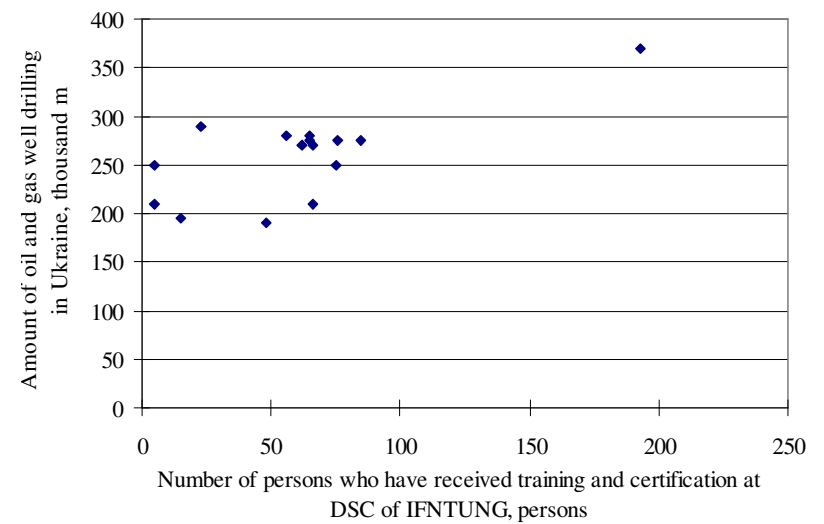

Fig. 4 Scatterplot of the studied indicators

We hypothesize that drilling volumes $(\mathrm{Y})$ will be linearly dependent on the number of persons who have received training and certification at DSC of IFNTUOG IFNTUNG (x). Then in the general case, the econometric model will look like:

$$
Y=b_{0}+b_{1 x}
$$

where:

$Y$-dynamics of volumes of drilling, thousand metres, $x$ - number of persons who have received training and certification at DSC of IFNTUNG, persons, b0, b1 - the model options to find.

The results of the calculations obtained with the "Data Analysis - Correlation" add-in in MS Excel are presented in Table 2 .

Table 2

Results of static characteristics calculation of the studied dependence

\begin{tabular}{lc}
\multicolumn{1}{c}{ Parameter (criterion) } & $\begin{array}{c}\text { Parameter } \\
\text { value (crite- } \\
\text { rion) }\end{array}$ \\
\hline Model parameter $b_{0}$ & 215.065 \\
Model parameter $b_{1}$ & 0.734 \\
Coefficient of approximation (determination) $R^{2}$ & 0.5296 \\
The correlation coefficient $r$ & 0.7277 \\
design criterion of Fisher test $F$ & 14.6376 \\
Tabular value of Fisher test $F$ ( $0.95 ; 1 ; 13)$ & 4.67 \\
The calculated $t$-statistic value for parameter $b_{0}$ & 15.0643 \\
The calculated $t$-statistic value for parameter $b_{1}$ & 3.8259 \\
Tabular value of $t$-statistics $t(0.95 ; 13)$ & 2.16 \\
The lower confidence interval value (at probability & 184.2229 \\
$\mathrm{P}=95 \%$ ) for $b_{0}$ & \\
The upper confidence interval value(at probability & 245.9074 \\
$\mathrm{P}=95 \%$ ) for $b_{0}$ & \\
The lower confidence interval value (at probability & 0.3194 \\
$\mathrm{P}=95 \%$ ) for $b_{1}$ & \\
The upper confidence interval value(at probability & 1.1480 \\
$\mathrm{P}=95 \%$ ) for $b_{1}$ & \\
\hline
\end{tabular}

Thus, the following econometric model was obtained:

$$
Y=215.065+0.734 x
$$

The results of the drilling volume prediction of oil and gas wells according to the obtained econometric model are shown in Fig. 5. 


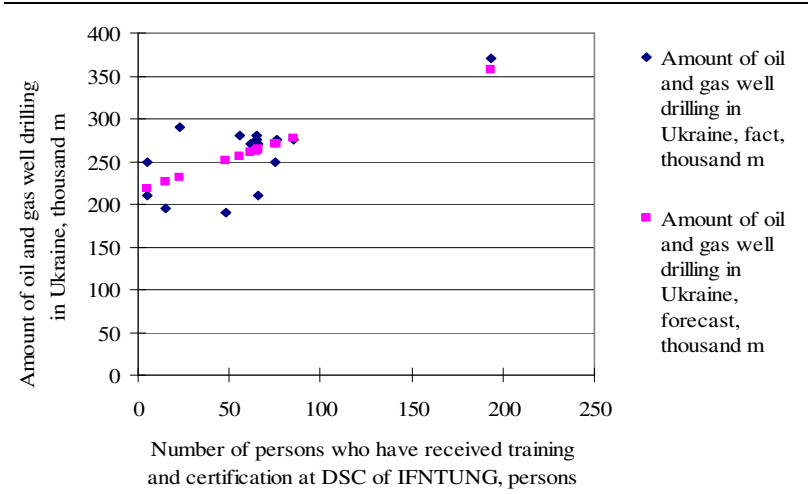

Fig. 5 The results of the drilling volume prediction of oil and gas wells according to the obtained econometric model

The value of the approximation coefficient $\mathrm{R} 2$ indicates that the model found makes it possible to explain the change in the drilling volume in $52.96 \%$ of cases by changing the number of persons who have received training and certification. The adequacy of the model can be proved by the value of the Fisher test. Since the found value of criterion $F$, which is equal to 14.6376 is greater than the table value, which is 4,67 , so the model is adequate to the original data with a probability of $95 \%$. The statistical reliability of the model's found parameters is verified on the basis of the calculated values of $t$-statistics. Therefore, since the calculated values of the t-criterion are larger than the table for both parameters, the model parameters found $b 0=215.065, b 1=0.734$ are statistically significant with a $95 \%$ probability.

\section{CONCLUSION}

The results of the calculations allow us to make sufficiently reliable assumptions about the certain influence of the number of persons who have been trained and certified on oil and gas wells drilling volumes. Thus, provided that the number of people who have received training and certification is zero, then the value of the drilling volume should be expected at 215.065 thousand meters, with a probability of $95 \%$ it can be argued that the minimum value will be 184.2229 thousand metres, and the maximum possible 245.9074 thousand metres. Accordingly, an increase in the number of persons who have been trained and certified per unit will allow to expect drilling volumes to rise at 0.734 thousand metres, with $95 \%$ probability to say that the minimum growth will be 0.3194 thousand metres and the maximum possible growth at the level of 1.1480 thousand metres.

In general, training and certification by international standards for drilling professionals makes them competitive in international labor markets and gives their employers a real opportunity to enjoy high priorities that contribute to the conclusion of profitable and long-term contracts. Systematic international certification of employees of oil and gas companies not only provides high quality knowledge and practical skills, but also contributes to the growth of exploration and production drilling and gives significant authority to the oil and gas industry of Ukraine in the international community.

\section{REFERENCES}

[1] H. Aguinis, M.L. Lengnick-Hall. "Assessing the value of human resource certification: A call for evidence-based human resource management." Human Resource Management Review, 2012, vol. 22, pp. 281-284. DOI: 10.1016/j.hrmr.2012.06.015

[2] H. Aguinis, S.E. Michaelis, N.M. Jones. "Demand for certified human resources professionals in internet-based job announcements." International Journal of Selection and Assessment, 2005, vol. 13, pp. 160-171.

[3] W.F. Cascio, H. Aguinis. "Research in industrial and organizational psychology from 1963 to 2007: Changes, choices, and trends." Journal of Applied Psychology, 2008, vol. 93, pp. 1062-1081. DOI: 10.1037/00219010.93.5.1062

[4] D.J. Cohen. "Identifying the value of HR certification: Clarification and more complex models required." Human Resource Management Review, 2012, vol. 22, pp. 258-265. DOI: 10.5296/ijhrs.v9i2.14459

[5] A.S. DeNisi. "Certification response: A response to Lengnick-Hall and Aguinis." Human Resource Management Review, 2012, vol. 22, pp. 266-268. DOI: 10.1016/j.hrmr.2012.03.003

[6] A.S. Garza, F.P. Morgeson. "Exploring the link between organizational values and human resource certification." Human Resource Management Review, 2012, 22, pp. 271278. DOI: 10.1016/j.hrmr.2012.06.011

[7] S. Kis, G. Kis "The personnel certification system as an important tool for human resources management development processes and their associations." Agricultural Entrepreneurship: Global Challenges and Effective Management: Proceedings of the 1st International Scientific and Practical Conference, Zaporizhia, Ukraine, 12-13.02.2020, in 2 parts, ZNU, Part 2, pp. 22-25. [in Ukrainian].

[8] S. Kis, G. Malynovska, V. Petrenko, O. Yatsiuk, "Matrix of Personality Intelligent Characteristics as an Instrument for its Development Management." Proceedings of the 6th International Conference on Strategies, Models and Technologies of Economic Systems Management (SMTESM 2019), in series: Advances in Economics, Business and Management Research [Online], Vol. 95, Khmelnytskyi, Ukraine, 46.10.2019. Available: https://www.atlantispress.com/proceedings/smtesm-19/125917672 [Feb. 21, 2020]. DOI: $10.2991 /$ smtesm-19.2019.64

[9] V.I. Kolisnyk, Yu.R. Mosora, V.I. Grymanyuk. "Increasing the Professional Competence of Specialists of the Oil and Gas Complex of Ukraine by Their International Certification." Machines, equipment and materials for increasing domestic production and diversification of oil and gas supply: Thesis of II International scientifictechnical conf., Ivano-Frankivsk, Ukraine, 24-27.04.2018, pp. 383-385.

[10] G.P. Latham. Becoming the evidence-based manager: Making the science of management work for you. Boston, MA: Davies-Black, 2009.

[11] M.L. Lengnick-Hall, H. Aguinis. "What is the value of human resource certification? A multi-level framework for research." Human Resource Management Review, 2012, vol. 22, pp. 246-257. DOI: 10.1016/j.hrmr.2011.03.001.

[12] S.W. Lester, J. Fertig, J. Dwyer. "Do business leaders value human resource certification." Journal of Leadership and Organizational Studies, 2012, vol. 48, pp. 408-414. DOI: $10.1177 / 1548051811404422$. 
[13] S.W. Lester, J. Mencl, C. Maranto, K.A. Bourne, T. Keaveny. "The impact of passing the professional in human resources exam on early career success for undergraduates entering the human resource field". International Journal of Selection and Assessment, 2010, vol. 18 pp. 282-290. DOI: 10.1111/j.14682389.2010.00511.x

[14] E.A. Locke. Handbook of principles of organizational behavior: Indispensable knowledge for evidence-based management. New York: Wiley, 2009.

[15] J. Mckillip, J. Owens. "Voluntary professional certifications: Requirements and validation activities". The Industrial Organizational Psychologist, 2000, vol. 38, pp. 50-57.

[16] Yu. Mosora, I. Kostryba, M. Bembenek. "Reliability of antiejection equipment as an important factor in improving safety during the construction and development of oil and gas wells". Geotechnologies, 2018, no. 1, pp. 65-71.

[17] R.A. Paxton. "A practitioner's perspective on the value of PHR and SPHR certification." Human Resource Management Review, 2012, vol. 22, pp. 279-280.

\section{Sviatoslav Kis}

ORCID ID: 0000-0001-9426-0951

Ivano-Frankivsk National Technical University of Oil and Gas

Department of Theory of Economics and Management Karpatska Street, 15, 76019, Ivano-Frankivsk, Ukraine e-mail: svjatkis@gmail.com

\section{Larysa Mosora}

ORCID ID: 0000-0003-4341-1937

Ivano-Frankivsk National Technical University of Oil and Gas

Department of Public Administration

Karpatska Street, 15, 76019, Ivano-Frankivsk, Ukraine e-mail: larysamosora85@gmail.com

\section{Yurii Mosora}

ORCID ID: 0000-0002-3192-7146

Ivano-Frankivsk National Technical University

of Oil and Gas

Department of Petroleum and Gas Equipment Karpatska Street, 15, 76019, Ivano-Frankivsk, Ukraine e-mail: yuramosora@gmail.com

\section{Oleh Yatsiuk}

ORCID ID: 0000-0002-3943-7352

Ivano-Frankivsk National Technical University

of Oil and Gas

Department of Theory of Economics and Management Karpatska Street, 15, 76019, Ivano-Frankivsk, Ukraine e-mail: olegstya@gmail.com
[18] D.M. Rousseau. Envisioning evidence-based management. In D. M. Rousseau (Ed.), Handbook of evidence-based management. New York: Oxford University Press. 2012.

[19] N. Volkova, A. Mullin, T. Sakhno. "Certification of personnel: a new version of the international standard ISO/IEC17024." Standardization. Certification. Quality, 2014, no. 4, pp. 50-58.

[20] V.S. Zaitsev. "Staff certification as a new technology for assessing the competencies of employees of enterprises." Donbass Economic Bulletin, 2017, no. 1 (47), pp. 119-125.

[21] Ya.L. Zakharchenko. "Personnel certification: a systematic approach." Bulletin of the National university "Lviv Polytechnic". Management and entrepreneurship in Ukraine: stages of development and development problems, 2013, no. 778, pp. 46-53.

\section{Galyna Malynovska}

ORCID ID: 0000-0003-3551-5648

Ivano-Frankivsk National Technical University

of Oil and Gas

Department of Theory of Economics and Management Karpatska Street, 15, 76019, Ivano-Frankivsk, Ukraine e-mail: oleg_st_ya@yahoo.com

\section{Serhii Pobihun}

ORCID ID: 0000-0002-2809-3312

Ivano-Frankivsk National Technical University

of Oil and Gas

Department of Entrepreneurship and Marketing Karpatska Street, 15, 76019, Ivano-Frankivsk, Ukraine e-mail: pobigunserg@gmail.com 